\title{
Comorbidity profiles among patients with ankylosing spondylitis
}

\author{
Ankilozan spondilitli hastalarda komorbidite profilleri
}

\author{
Yesim GARIP, Filiz ESER, Tuba GULER, Fulya DORTBAS, Aysegul KILICARSLAN, Hatice BODUR
}

\begin{abstract}
Objectives: We aimed to evaluate comorbidities and their association with clinical parameters in patients with ankylosing spondylitis (AS).

Patients and Methods: A hundred and ten AS patients were included. Disease activity was evaluated by Bath Ankylosing Spondylitis Disease Activity Index (BASDAI), functional status by Bath Ankylosing Spondylitis Functional Index (BASFI), spinal mobility Bath Ankylosing Spondylitis Metrology Index (BASMI) and quality of life by Nottingham Health Profile (NHP).

Results: Comorbidities were detected in $28.18 \%$ of the patients. These were peptic ulcer (20.91\%), hypertension $(20 \%)$, lung disease (15.45\%), diabetes mellitus (13.64\%), osteoporosis (10.91\%), ischemic heart disease (10\%), renal diseases (Ig A nephropathy and renal papillary necrosis, $1.82 \%$ ) and cancers (papillary thyroid carcinoma and renal cell ca, 1.82\%), respectively. Patients with comorbidities scored significantly higher in BASDAI, BASMI, BASFI, VAS-pain, and pain, physical mobility, and energy subgroups of NHP $(\mathrm{p}<0.05)$. Peripheral involvement was observed in $27.27 \%$ of the patients. The frequency of comorbidities was higher in the patients with peripheral involvement (Pearson $\left.\mathrm{X}^{2}=54.725, \mathrm{p}<0.01\right)$.
\end{abstract}

Yesim Garip (四)

Physical Medicine and Rehabilitation Clinic, Pinar Physical Medicine and Therapy Center, Ankara, Turkey

e-mail: dryesimgarip@gmail.com

Filiz Eser, Aysegul Kilıcarslan, Hatice Bodur

Physical Medicine and Rehabilitation Clinic, Numune Training and Research Hospital, Ankara Turkey

Tuba Guler

Physical Medicine and Rehabilitation Clinic, Derince Training and Research Hospital, Kocaeli, Turkey

Fulya Dortbas

Pheumatology Clinic, Derince Training and Research Hospital, Kocaeli, Turkey

Submitted/Gönderilme: 12.11 .2015

Accepted/Kabul: 29.12.2015
Conclusion: Comorbid conditions of AS are associated with more active disease, functional impairment and deterioration in quality of life. Therefore, comorbidities should be detected and treated earlier in order to reduce their negative impact on disease outcome.

Keywords: Ankylosing spondylitis, Comorbidity, Disease activity, Quality of life

ÖZ

Amaç: Ankilozan spondilit (AS) hastalarındaki komorbiditeleri ve klinik parametrelerle ilişkisini değerlendirmeyi amaçladık.

Hastalar ve Yöntem: Çalışmaya 110 AS hastası dahil edildi. Hastalık aktivitesi Bath Ankilozan Spondilit Hastalık Aktivite İndeksi [Bath Ankylosing Disease Activity Index (BASDAI)] ile, fonksiyonel durum Bath Ankilozan Spondilit Fonksiyonel İndeks [Bath Ankylosing Spondylitis Functional Index (BASFI)] ile, spinal mobilite Bath Ankilozan Spondilit Metroloji İndeksi [Bath Ankylosing Spondylitis Metrology Index (BASMI)] ile ve yaşam kalitesi ise Nottingham Sağlık Profili [Nottingham Health Profile (NHP)] ile değerlendildi.

Bulgular: Hastaların \%28,18'inde komorbidite saptand1. Bunlar sirası ile peptik ülser (20,91\%), hipertansiyon (\%20), akciğer hastalığ1 $(\% 15,45)$, diabetes mellitus $(\% 13,64)$, osteoporoz $(\% 10,91)$, iskemik kalp hastalığ1 $(\% 10)$, böbrek hastalıkları (Ig A nefropatisi ve renal papiller nekroz, \%1,82) ve kanserler (papiller tiroid kanseri ve renal hücreli kanser, \%1,82) idi. Komorbiditesi bulunan hastalar BASDAI, BASMI, BASFI, VAS-ağrı ve NHP'nin ağrı, fiziksel mobilite ve enerji alt gruplarında belirgin olarak yüksek skorlama gösterdiler $(\mathrm{p}<0,05)$. Periferik tutulum hastaların \%27,27'sinde gözlendi. Komorbidite sıklığ 1 periferik tutulumlu hastalarda daha fazlayd 1 (Pearson $\mathrm{X}^{2}=54,725, \mathrm{p}<0,01$ ).

Sonuç: AS'nin komorbid durumları, daha aktif hastalık, fonksiyonel kısıtlılık ve yaşam kalitesinde bozulma ile ilişkilidir. $\mathrm{Bu}$ neden ile hastalık sonuçlarına olumsuz etkileri azaltmak için bu komorbiditelerin erken tespit edilip tedavi edilmesi gereklidir.

Anahtar kelimeler: Ankilozan spondilit, Komorbidite, Hastalık aktivitesi, Yaşam kalitesi 


\section{Introduction}

Ankylosing spondylitis (AS) is a common inflammatory rheumatic disease which belongs to the spondyloarthritis group. It affects the axial skeleton, causing characteristic inflammatory back pain [1]. Peripheral joint involvement usually appears in lower extremities. Peripheral involvement which occurs in the early stages of the disease predicts more aggressive disease [2].

Patients with AS frequently suffer from comorbidities [3]. Comorbidities may either be linked to the disease process, to the treatment, or may be an independent finding and they contribute to the burden of the disease. Hypertension, ischemic heart diseases, diabetes mellitus and osteoporosis have been found to be increased in people with AS [4].

Health-related quality of life (HRQoL) is defined as "individuals' perception of their position in life in the context of the culture and value systems in which they live and in relation to their goals, expectations, standards and concerns" by World Health Organization [5]. HRQoL is an outcome measure that is increasingly being used to evaluate health outcome in clinical studies of patients with rheumatic disorders including AS [6]. Comorbidities in rheumatic disorders lead to functional impairment, worse HRQoL and mortality [7]. They add to the complexity of diagnosis, prognosis and treatment of the disease. Understanding the natural course, causes and impacts of comorbidities will help us in the treatment and management of the disease [8].

The main objectives of the present study were i) to examine the comorbidities in Turkish patients with AS; ii) to assess the association between peripheral involvement and presence of comorbidities and; iii) to evaluate the impact of comorbidities on HRQoL in terms of disease activity, functional status, severity of pain, and social and emotional functioning.

\section{Patients and Methods}

A total of $110 \mathrm{AS}$ patients ( 75 males and 35 females) followed at outpatient physical medicine and rehabilitation and rheumatology clinics of two training and research hospitals were included in the study. All of the patients fulfilled the modified New York criteria [9]. Patients were evaluated by using Assessment of SpondyloArthritis International Society (ASAS) recommendations for core outcome domains for the assessment in AS [10]. Patient data regarding age, gender, body mass index (BMI), duration of the disease and history of peripheral involvement were recorded. Peripheral involvement was accepted as pain, swelling or limitations of peripheral joints. Patients were asked to complete the questionnaire regarding the comorbidities such as ischemic heart disease, hypertension, diabetes mellitus, osteoporosis, peptic ulcer, osteoporosis, lung diseases, renal diseases and cancers, and then presence of comorbidities was confirmed by the data extracted from patient records. Patient records comprised serum biochemistry tests; echocardiography and electrocardiogram, chest x-ray and thoracic computed tomography; upper gastrointestinal endoscopy; dual-energy x-ray absorptiometry (DEXA) and physical examination reports regarding the comorbidities. Erythrocyte sedimentation rate (ESR, $\mathrm{mm} /$ hour) was measured by Westergren tube method and C-reactive protein (CRP, mg/ dl) by nephelometric method. $10 \mathrm{~cm}$ Visual Analog ScalePain (VAS-pain) was used to determine the severity of pain [11]. Disease activity was evaluated by using Turkish version of Bath Ankylosing Spondylitis Disease Activity Index (BASDAI) [12]. The Bath Ankylosing Spondylitis Functional Index (BASFI) was used for determining functional status [13]. HRQoL was assessed by using Nottingham Health Profile (NHP) [14]. Spinal mobility was measured by using The Bath Ankylosing Spondylitis Metrology Index (BASMI) [15].

Written informed consent was signed by all of the patients. Medical Research Ethics Committee approved the study protocol. Our study conforms to the provisions of the World Medical Association's Declaration of Helsinki.

\section{Statistical Analyses}

Descriptive statistics [mean, median, SD (Standard deviation), minimum, maximum and frequencies] were used for assessing the demographics and clinical parameters. Differences between patients with and without comorbidities were assessed using independent samples T-test. Differences between patients with and without peripheral arthritis were evaluated using chi-square test. Logistic regression analysis was used to determine the effects of age, gender and BMI on comorbidities. A value of $\mathrm{p}<0.05$ was considered statistically significant. All analyses were performed using IBM Statistical Package for the Social Sciences (SPSS) for Windows, Version 21.0 (Armonk, New York, USA).

\section{Results}

\section{Sociodemographic characteristics}

A total of 110 AS patients ( 75 males and 35 females) were included in the study. Male-female ratio was 2.14. Mean age was $40.38 \pm 9.83$ (21-71). Mean disease duration was

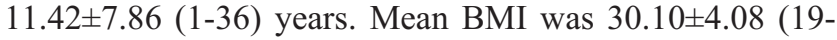
39). Mean value was $25.47 \pm 18.96$ for ESR, $20.90 \pm 14.22$ for CRP, and 5.06 \pm 3.19 for VAS-pain. 


\section{Comorbidities}

Comorbidities were reported in 31 patients $(28.18 \%)$. The most common was peptic ulcer (23 patients, $20.91 \%$ ). This was followed by hypertension (22 patients, 20\%), lung disease (17 patients, $15.45 \%$ ), diabetes mellitus (15 patients, $13.64 \%$ ), osteoporosis (12 patients, 10.91\%), ischemic heart disease (11 patients, 10\%), renal diseases [2 patients (Ig A nephropathy and renal papillary necrosis), 1.82\%) and cancers [2 patients (papillary thyroid carcinoma and renal cell ca), 1.82\%], respectively (Table I).

Table I. Prevalence of comorbidities in 110 AS patients $(n=50)$

\begin{tabular}{ll}
\hline Comorbidities & $\begin{array}{l}\text { Number } \\
\text { (percentage) }\end{array}$ \\
\hline Peptic ulcer & $23(20.91)$ \\
Hypertension & $22(20)$ \\
Lung diseases (asthma, chronic obstructive & $17(15.45)$ \\
pulmonary disease) & \\
Diabetes mellitus & $15(13.64)$ \\
Osteoporosis & $12(10.91)$ \\
Ischemic heart disease & $11(10)$ \\
Renal disease & $2(1.82)$ \\
Cancers & $2(1.82)$ \\
\hline
\end{tabular}

Patients with comorbidities scored significantly higher in BASDAI, BASMI, BASFI, VAS-pain, and in the pain, physical mobility, and energy subgroups of NHP $(p<0.05)$ (Table II).

Table II. The relation between presence of comorbidities and clinical parameters

\begin{tabular}{|c|c|c|c|}
\hline & \multicolumn{3}{|c|}{ Comorbidities } \\
\hline & $\begin{array}{l}\text { Present } \\
(n=50)\end{array}$ & $\begin{array}{l}\text { Absent } \\
(n=60)\end{array}$ & P value \\
\hline BASDAI & $5.05 \pm 2.08$ & $3.67 \pm 1.38$ & $0.003 * *$ \\
\hline BASMI & $4.27 \pm 2.43$ & $3.23 \pm 2.34$ & $0.044^{*}$ \\
\hline BASFI & $5.75 \pm 2.06$ & $2.40 \pm 1.72$ & $<0.001 * *$ \\
\hline VAS-pain & $6.86 \pm 2.24$ & $3.59 \pm 3.01$ & $<0.001 * *$ \\
\hline NHP-pain & $54.41 \pm 27.15$ & $43.34 \pm 29.28$ & $0.043 *$ \\
\hline NHP-physical mobility & $46.00 \pm 30.77$ & $32.7 \pm 30.72$ & $0.026^{*}$ \\
\hline NHP- energy & $52.00 \pm 40.35$ & $30.33 \pm 36.83$ & $0.004 * *$ \\
\hline NHP- sleep & $42.4 \pm 30.94$ & $33.44 \pm 30.71$ & 0.13 \\
\hline NHP-social isolation & $38.4 \pm 33.28$ & $28.52 \pm 27.08$ & 0.91 \\
\hline $\begin{array}{l}\text { NHP-emotional } \\
\text { reactions }\end{array}$ & $40.85 \pm 35.17$ & $35.24 \pm 31.83$ & 0.381 \\
\hline
\end{tabular}

BASDAI: Bath Ankylosing Spondylitis Disease Activity Index, BASMI: Bath Ankylosing Spondylitis Metrology Index, BASFI: Bath Ankylosing Spondylitis Functional Index, VAS: Visual Analog Scale, NHP: Nothingham Health Profile, *: $p<0.05$ (significant), **: $p<0.01$ (highly significant)

\section{Peripheral joint involvement}

Peripheral involvement was reported in $27.27 \%$ of the patients (30 patients) during the disease course. Of all these cases, $66.67 \%$ the hips (20 patients), in $56.67 \%$ the knees (17 patients), in $10 \%$ the shoulders ( 3 patients) and in $6.67 \%$ the ankles ( 2 patients) were affected.

The frequency of comorbidities was higher in the patients with peripheral involvement as compared to the patients without peripheral involvement (Pearson $\mathrm{X}^{2}=54.725$, $\mathrm{p}<0.01$ ) (Table III).

Table III. The relation between presence of peripheral arthritis and comorbidities

\begin{tabular}{lccccc}
\hline & & \multicolumn{2}{c}{ Comorbidities } & P value \\
& & absent & present & total & \\
\hline $\begin{array}{l}\text { Peripheral } \\
\text { arthritis }\end{array}$ & absent & 73 & 7 & 80 & $<0.0001^{* *}$ \\
& present & 6 & 24 & 30 & \\
& total & 79 & 31 & 110 & \\
\hline
\end{tabular}

Pearson chi-square $=54.725,{ }^{* *}: \mathrm{p}<0.01$ (highly significant)

\section{Impact of age, gender and BMI on comorbidities}

Multiple regression analysis revealed no impact of age, gender or BMI on comorbidities ( $p>0.05$ ). $\beta$ coefficients and adjusted $\mathrm{R}^{2}$ values are given in Table IV.

Table IV. Impact of age, gender and BMI on comorbidities in the patients with AS

\begin{tabular}{lll}
\hline & $\begin{array}{l}\text { Presence of comorbidities } \\
\text { (Adjusted } \boldsymbol{R}^{\mathbf{2}} \mathbf{0 . 0 6 4 )}\end{array}$ \\
\hline Variables & $\boldsymbol{\beta}$ & P value \\
Age & 0.012 & 0.009 \\
Gender & 0.008 & 0.928 \\
BMI & 0.002 & 0.863 \\
\hline
\end{tabular}

BMI: Body mass index

\section{Discussion}

Our study demonstrates that AS is associated with a high prevalence of comorbidities. We found the rate of 
comorbidities as $28.18 \%$. The most common comorbidities were peptic ulcer (20.91\%), hypertension (20\%) and lung diseases (15.45\%). Diabetes mellitus (13.64 \%), osteoporosis $(10.91 \%)$, ischemic heart disease $(10 \%)$, renal diseases $(1.82 \%)$ and cancers $(1.82 \%)$ followed these, respectively. We compared our results with larger cohorts. Turkiye Romatizma Arastirma ve Savas Dernegi [TRASD] (Turkish League Against Rheumatism) data base comprising 1,381 Turkish patients with AS revealed the rate of comorbidities as follows: peptic ulcer (8.8\%), hypertension (7.5\%), cardiac disease (3.6\%) and diabetes mellitus (3\%) [16]. High percentage of comorbidities in our series is remarkable. This may be due to our patient selection criteria. Our group of patients included mostly severe ones who require regular controls in a tertiary hospital. The frequency of comorbidities in AS patients differs from one country to another. This situation may be explained by including genetic factors and geographic differences in lifestyles and eating behaviors. In emAR study from another Mediterranean country, Spain, the most common conditions were reported as hypertension (17.4\%), peptic ulcer (6.8\%) and diabetes mellitus (6.1\%) [17]. In a study which was conducted in United Kingdom, prevalence of overall comorbidities was reported as $50 \%$. The most common was hypertension with a rate of $17 \%$ [18]. In a study performed in another European country, Sweden, the rates of comorbidities were lower than in our series. Ischemic heart disease was seen in $2.2 \%$ of the patients. Hypertension (1.98\%) and diabetes mellitus (1.41\%) followed it, respectively [4]. In a study from Taiwan, the most frequent comorbidities in the patients with AS were reported as hypertension (16.4\%), peptic ulcer (13.9\%) and headache (10.2\%) [3].

Ankylosing spondylitis involves frequently the axial skeleton, and peripheral joint involvement is observed in 20-35\% of patients [19]. In agreement with these observations, peripheral joint involvement was $27.27 \%$ in our patients. In $66.67 \%$ the hips, in $56.67 \%$ the knees, in $10 \%$ the shoulders and in $6.67 \%$ the ankles were influenced. In a study of Brunner et al. [20] which was conducted on 1177 AS patients in Switzerland, peripheral involvement was reported as $31.5 \%$. In $58 \%$ of the cases the hips, in $35 \%$ the shoulders, and in $31 \%$ the knees were affected. Rate of shoulder involvement was much higher than ours. In REGISPONSER study conducted on 1,385 Spanish patients with AS, frequency of peripheral involvement was found as $17.4 \%$ [21]. In emAR study, peripheral arthritis was reported in $54.8 \%$ of the patients [17]. They explained this high percentage by the dominance of psoriatic arthritis or undifferentiated spondyloarthritis in their series. Tayel et al. [22] reported the peripheral joint involvement as $32 \%$ in Indian patients with AS.

We found that the frequency of comorbidities was higher in the patients with peripheral involvement when compared with those without peripheral involvement. To our knowledge, this is the first study to demonstrate an association between the presence of peripheral joint involvement and comorbidities in AS patients. This association might result from the disease process or the treatment. Peripheral arthritis is associated with inflammation. Inflammation may also initiate or worsen comorbid diseases such as ischemic heart disease, osteoporosis, depression and diabetes. Additionally, multiple drug use due to peripheral arthritis is associated with increased potential for comorbid conditions such as peptic ulcer and hypertension. Due to the cross-sectional design of the study, we could not determine the cause-effect relationships. Further longitudinal studies are needed.

The present study investigated the effect of comorbidities on HRQoL including physical, social, and emotional functions, and pain. The relationship between the presence of comorbidities and disease activity, functional status, and pain was evaluated. Presence of comorbidities was found to be associated with disease activity, functional status and pain. This might result from increased drug use due to worsening of the disease. Additionally, we demonstrated that comorbidities had a significant negative impact on HRQoL in terms of pain, physical mobility, and energy. However HRQoL domains including sleep, social and emotional functions were not affected by comorbidities. In the literature, there are a few studies which assess the relation of comorbidities with HRQoL and clinical parameters in AS patients. In the study of Stolwijk et al. [8], where the comorbidities were evaluated by using Self-administered Comorbidity Questionnaire, it was found that the comorbidities were correlated with functional disability, higher disease activity and impaired HRQoL in the patients with AS. Similarly, Ariza-Ariza et al. [23] reported lower HRQoL scores in terms of mobility, self-care, pain and psychological status in Spanish patients with comorbidities. Boonen et al. [24] indicated functional impairment and deterioration in physical and social functions, vitality and mental health domains of HRQoL in AS patients with comorbidities. In the study of Salaffi et al. [25], where disease activity was determined by using BASDAI, it was reported that the patients with comorbidities had severe disease.

Our study has several limitations. First one is relatively small number of subjects. And secondly, we did not 
review the medication used which can be associated with comorbidities. Third, cause-effect relationships cannot be determined. For this reason, a longitudinal study is necessary.

The present study also investigated the effect of age, gender and BMI on comorbidities in the patients with AS. We found no impact of these parameters on presence of comorbidities. It was unexpected that frequency of comorbidities did not increase with age. In normal population, comorbidities increase with age; however in patients with AS, due to the effects of disease activity, there may not be a direct association between comorbidities and increasing age. Kang et al. [3] indicated a gender difference in comorbidities associated with AS, however, they did not report which comorbidities were common in men or women. To our knowledge, our study was to first to investigate impact of BMI on comorbidities in the patients with AS.

In conclusion, comorbidities are associated with more active and severe disease and functional impairment in the patients with AS. They have a negative impact on HRQoL in terms of physical functioning, and vitality. Monitoring of comorbidities should be involved in clinical practice. Regular monitoring of renal functions and hypertension is needed for the patients on long term NSAID therapy. Comorbidities should be detected and taken into consideration in the choice of medical treatment.

\section{References}

1. Braun J, Sieper J Ankylosing spondylitis. Lancet 2007; 369: 1379-90.

2. Gensler L. Clinical features of ankylosing spondylitis. In: MC Hochberg, AJ Silman, JS Smolen, ME Weinblatt, MH Weisman, editors. Rheumatology. $5^{\text {th }}$ ed. Philadelphia: Mosby Elsevier, 2009: 1129-34.

3. Kang JH, Chen YH, Lin HC. Comorbidity profiles among patients with ankylosing spondylitis: a nationwide populationbased study. Ann Rheum Dis 2010;69: 1165-8. doi: 10.1136/ ard.2009.116178.

4. Bremander A, Petersson IF, Bergman S, Englund $\mathrm{M}$. Population-based estimates of common comorbidities and cardiovascular disease in ankylosing spondylitis. Arthritis Care Res (Hoboken) 2011;63:550-6. doi: 10.1002/acr.20408.

5. Study protocol for the World Health Organization project to develop a Quality of Life assessment instrument (WHOQOL). Qual Life Res 1993;2:153-9.

6. Fortin M, Dubois MF, Hudon C, Soubhi H, Almirall J. Multimorbidity and quality of life: a closer look. Health Qual Life Outcomes 2007;5:52. doi: 10.1186/1477-7525-552

7. Stolwijk C, van Tubergen A, Ramiro S, et al. Aspects of validity of the self-administered comorbidity questionnaire in patients with ankylosing spondylitis. Rheumatology (Oxford) 2014;53:1054-64.
8. Mercieca C, van der Horst-Bruinsma IE, Borg AA. Pulmonary, renal and neurological comorbidities in patients with ankylosing spondylitis; implications for clinical practice. Curr Rheumatol Rep 2014;16:434. doi: 10.1007/s11926-0140434-7.

9. Moll JM. New criteria for the diagnosis of ankylosing spondylitis. Scand J Rheumatol Suppl 1987;65:12-24

10. Sieper J, Rudwaleit M, Baraliakos X, et al. The Assessment of SpondyloArthritis International Society (ASAS) handbook: a guide to assess spondyloarthritis. Ann Rheum Dis 2009;68:144. doi:10.1136/ard.2008.104018

11. Price DD, McGrath P, Rafii A, Buckingham B. The validation of visual analogue scales as ratio scale measures for chronic and experimental pain. Pain 1983; 17:45-56.

12. Akkoc Y, Karatepe AG, Akar S, Kirazli Y, Akkoc N. A Turkish version of the Bath Ankylosing Spondylitis Disease Activity Index: reliability and validity. Rheumatol Int 2005;25:280-4.

13. Calin A, Garrett S, Whitelock H, et al. A new approach to defining functional ability in ankylosing spondylitis: the development of the Bath Ankylosing Spondylitis Functional Index. J Rheumatol 1994;21:2281-5

14. Küçükdeveci AA, Mc Kenna SP, Kutlay S, Gürsel Y, Whalley $\mathrm{D}$, Arasil T. The development and psycometric assessment of the Turkish version of the Nottingham Health Profile. Int J Rehabil Res 2000;23:31-8

15. Jenkinson TR, Mallorie PA, Whitelock HC, Kennedy LG, Garrett SL, Calin A. Defining spinal mobility in ankylosing spondylitis (AS): The Bath AS Metrology Index. J Rheumatol 1994;21:1694-8.

16. Bodur H, Ataman S, Buğdayci DS, et al. Description of the registry of patients with ankylosing spondylitis in Turkey: TRASD-IP. Rheumatol Int 2012;32:169-76. doi: 10.1007/ s00296-010-1599-7

17. Casals-Sánchez JL, García De Yébenes Prous MJ, Descalzo Gallego MÁ, et al. Characteristics of patients with spondyloarthritis followed in rheumatology units in Spain. emAR II study. Reumatol Clin 2012;8:107-13

18. Ara RM, Packham JC, Haywood KL. The direct healthcare costs associated with ankylosing spondylitis patients attending a UK secondary care rheumatology unit. Rheumatology (Oxford) 2008;47:68-71.

19. Bostan EE, Borman P, Bodur H, Barca N. Functional disability and quality of life in patients with ankylosing spondylitis. Rheumatol Int 2003; 23: 121-6.

20. Brunner R, Kissling RO, Auckenthaler C, Fortin J. Clinical evaluation of ankylosing spondylitis in Switzerland. Pain Physician 2002; 5: 49-56.

21. Collantes E, Zarco P, Muñoz E, et al. Disease pattern of spondyloarthropathies in Spain: description of the first national registry (REGISPONSER) extended report. Rheumatology (Oxford) 2007;46:1309-15.

22. Tayel MY, Soliman E, El Baz WF, El Labaan A, Hamaad Y,Ahmed MH. Registry of the clinical characteristics of spondyloarthritis in a cohort of Egyptian population. Rheumatol Int 2012; 32:2837-42. doi: 10.1007/s00296-011-2068-7

23. Ariza-Ariza R, Hernández-Cruz B, López-Antequera G, Navarro-Sarabia F. Variables related to utility in patients with ankylosing spondylitis. Clin Rheumatol 2009;28: $207-$ 11. doi: 10.1007/s10067-008-1019-5 
24. Boonen A, Chorus A, Miedema $\mathrm{H}$, et al. Withdrawal from labour force due to work disability in patients with ankylosing spondylitis. Ann Rheum Dis 2001; 60: 1033-9.

25. Salaffi F, Carotti M, Gasparini S, Intorcia M, Grassi W. The health-related quality of life in rheumatoid arthritis, ankylosing spondylitis, and psoriatic arthritis: a comparison with a selected sample of healthy people. Health Qual Life Outcomes 2009;7:25. doi: 10.1186/1477-7525-7-25 